\title{
ELEKTROCHEMOTERAPIJOS VEIKSMINGUMAS, GYDANT PIKTYBINIUS NAVIKUS: LITERATŪROS APŽVALGA IR KLINIKINIS ATVEJIS
}

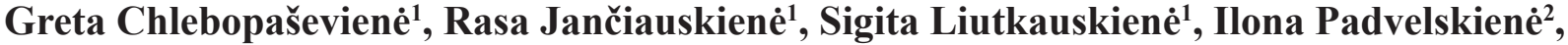 \\ Saulius Šatkauskas ${ }^{3}$, Elona Juozaityté ${ }^{1}$ \\ ${ }^{1}$ Lietuvos sveikatos moksly universiteto Medicinos akademijos Onkologijos institutas, \\ ${ }^{2}$ Lietuvos sveikatos mokslu universiteto Kauno klinikos, ${ }^{3}$ Vytauto Didžiojo universitetas
}

Raktažodžiai: elektrochemoterapija, Kapoši sarkoma, cisplatina, bleomicinas.

\begin{abstract}
Santrauka
Chemoterapija yra standartizuotas véžio gydymas vienu ar keliais vaistais, naikinančiais navikines ląsteles ar stabdančiais jų augimą. Chemoterapijos galimybès dar labiau padideja, taikant ją su kitais piktybinių navikų gydymo būdais (chirurgija, radioterapija), tačiau gydant tam tikrų lokalizacijų navikus, chemoterapija nèra veiksminga. Kartais tai lemia vaisto biologinès savybès (hidrofiliškumas, didelè molekulinè masè), todèl jis blogai prasiskverbia pro navikinès ląstelès membraną ir nesukelia laukiamo efekto. Siekiant norimo poveikio, šio vaisto turi būti skiriama didelèmis dozėmis - dèl to pasireiškia vaisto nepageidaujamas poveikis. Vienas iš būdų padidinti priešnavikinių vaistų veiksmingumą, yra elektrinių impulsų derinimas su vaistais nuo vėžio. Šis metodų derinys pavadintas elektrochemoterapija (ECT). Elektriniai impulsai sukelia pokyčių ląstelès membranoje: vyksta jos destabilizacija, formuojasi laikinos ,poros“ (elektroporacija), dèl to padideja membranos laidumas jos išoreje esančioms medžiagoms, ir vaistas, kuris normaliomis sąlygomis sunkiai prasiskverbia ị ląstelès vidų, lengvai pasiekia taikini.
\end{abstract}

\section{Ivadas}

Elektrochemoterapija - navikų gydymas derinant citotoksinius vaistus, kurie sunkiai prasiskverbia (arba ne) per plazminę membraną, su vietine navikinių ląstelių elektroporacija [1]. Elektrochemoterapijos metodas yra patvirtintas ir plačiai naudojamas pasaulyje radikaliems ir paliatyviems tikslams.

Pirmasis klinikinis tyrimas, atliktas 1991 m. Paryžiuje, ịrodė elektrochemoterapijos efektyvumą, gydant galvos kaklo naviko metastazes odoje [2]. Po to buvo inicijuotos kitos klinikinès studijos, kurių metu elektroporacija taikyta derinyje su bleomicinu ar cisplatina, skiriant chemopreparatą ị veną ar vietiškai į navikinius pažeidimus odoje. Buvo gydomos įvairių navikų, tokių kaip galvos ir kaklo plokščiujų ląstelių karcinomos, piktybinès melanomos, bazalinių ląstelių karcinomos, krūties ir seilių liaukų adenokarcinomos, Kapoši sarkomos ir šlapimo pūslès pereinamojo epitelio ląstelių karcinomos, metastazès odoje [3,4].

1991-2003 m. laikotarpiu klinikiniuose tyrimuose elektochemoterapijos metodu iš viso buvo gydyti 247 pacientai, elektroporuoti 1009 pažeidimai odoje [5]. Bendri šių tyrimų rezultatai parode, jog elektrochemoterapija yra veiksmingas gydymo metodas: bendras atsako dažnis, kai metastazès odoje sumažejo, pasiektas 48-100 proc. atvejų. İ gydymą geriau reagavo mažesnès ir plonesnès odos metastazès, kai visa naviko masė galëjo būti elektroporuota vienmomentiškai. Kai kuriais atvejais gydymas buvo kartojamas.

Irodyta, jog nepriklausomai nuo histologinio naviko tipo, ECT yra veiksminga paliatyviai gydant odos, poodžio navikus bei metastazes odoje. Taip pat ji gali būti skiriama neoadjuvantiniam tikslui, siekiant sumažinti navikinio pažeidimo tūrị prieš operaciją.

Siekiant geresnio atsako ị gydymą, naviko mazgeliai (pažeidimai) turi būti lengvai pasiekiamoje vietoje, nedidelio ploto, kad būtų kuo mažesnis elektros impulsų skaičius. Gydymas nerekomenduojamas, jei yra visceralinių metastazių, kurios greitai progresuoja.

Vis dèlto ECT gali pagerinti paciento gyvenimo kokybę, neatsižvelgiant ị numatomą gyvenimo trukmę, išgydyti skausmingus ar kraujuojančius pažeidimus. Taip pat gali pasitarnauti kosmetiniams tikslams, turintiems ịtakos paciento socialinei gerovei, gali išsaugoti organo funkciją, o esant pavienių židinių, netgi išgydyti pacientą [6].

$2018 \mathrm{~m}$. paskelbtos atnaujintos elektrochemoterapijos taikymo rekomendacijos. Ruošiant šị dokumentą, dalyvavo 
Europos dermatologų, bendrosios chirurgijos gydytojų, galvos ir kaklo chirurgu, plastikos chirurgų bei onkologų ekspertų grupè [7].

Tyrimo tikslas - išanalizuoti ir aptarti ịrodymais pagrịstą informaciją apie elektrochemoterapijos metodo galimybes, efektyvumą, gydant skirtingų lokalizacijų navikus bei pristatyti sèkmingą Kapoši sarkomos gydymo atvejị.

\section{Tyrimo medžiaga ir metodai}

Taikyta sisteminė mokslinès literatūros bei dokumentų apžvalga ir analizè. Duomenų buvo ieškoma UpToDate bei Medline (PubMed) duomenų bazèse. Visateksčiai straipsniai atrinkti, jei jų pavadinimas, santrauka ar reikšminiai žodžiai nurodè, kad tyrimas tinkamas šiai apžvalgai. Analizei atrinktos ir išanalizuotos 25 publikacijos.

\section{Tyrimo rezultatai}

Elektrochemoterapijos metodologija. Elektrochemoterapijos metu naudojamas elektroporatorius - elektros ịrenginys, formuojantis stačiakampio ar kitos formos elektrinius impulsus, kurių parametrus (trukmę, amplitudę, skaičių, dažnį) galima keisti tam tikrose ribose. Kiekvienas elektroporatorius susideda iš impulsų generavimo, perdavimo ir registravimo sistemu.

Elektriniai impulsai gali būti perduodami skirtingų tipų elektrodais. Yra du pagrindiniai elektrodų tipai: plokštelès formos ir adatiniai. Kokie elektrodai bus naudojami, priklauso nuo navikinio pažeidimo lokalizacijos. Plokštelès formos elektrodai su skirtingais tarpais naudojami nedideliems paviršiniams navikams gydyti. Infiltratyviai i gyli augantiems navikams naudojami adatiniai elektrodai. Dar yra sukurti ant piršto uždedami elektrodai, kurie naudojami gleivinès pažeidimų gydymui.

Klinikinių tyrimų duomenimis, įrodytas dviejų chemopreparatu (bleomicino ir cisplatinos) vartojimo tikslingumas. Bleomicinas gali būti skiriamas dviem būdais, t.y. suleidžiant jị ị veną arba tiesiai ị navikini pažeidimą (intranavikinis). Intranavikinis vaisto skyrimo būdas rekomenduojamas, kai pažeidimas nedidelis arba pažeidimų skaičius yra mažesnis nei 7. Tuo atveju, kai odos navikas arba metastazės odoje užima didesnį paviršiaus plotą arba stebima daug pažeidimų - chemoterapija turètų būti skiriama ị veną. Cisplatina skiriama tik intranavikiniu būdu.

Indikacijos. Elektrochemoterapija skiriama, kai operacinis gydymas negalimas, navikas rezistentiškas chemoterapijai ar radioterapijai. ECT veiksmingumas yra panašus arba net didesnis, palyginti su kitomis abliacinemis odos terapijomis, pvz. fotodinamine terapija, radioterapija, intranavikine terapija. Metodas tinkamas vyresniems pacientams, kuriu išnaudotos kitos gydymo galimybės ar turintiems sunkių gretutinių susirgimų. ECT naudojama ne tik naviko gydymui, bet ir paliatyviam tikslui, siekiant sumažinti naviką, taip sumažinat skausminį sindromą ar kraujavimo riziką. Tai gali pagerinti pacientų gyvenimo kokybę, valdant ịvairius navikinius susirgimus.

Procedūra lengva ir trumpa (25-30 min.), susijusi su trumpa hospitalizacija. Šalutinis poveikis minimalus, daugumai pacientų po procedūros analgetikų neprireikia. Priešingai nei radioterapijos metu, elektrochemoterapijos ciklai gali būti kartojami, ECT gali būti derinama su kitais gydymo metodais ligai progresuojant, ar siekiant sustiprinti gydymo efektyvumą [8]. Elektrochemoterapija yra ekonomiškai pranašesnis gydymo metodas, palyginus šios procedūros kainos - efektyvumo santykị su kitais odos ir poodžio melanomos gydymo metodais [9].

ECT daugelyje Europos valstybių yra ịprastinis gydymo metodas. Jungtinès Karalystès Nacionalinio sveikatos ir klinikinès kompetencijos instituto (NICE) rekomendacijose elektrochemoterapijos metodu siūloma gydyti sudètingos lokalizacijos pirminę bazalinių ląstelių karcinomą, odos plokščiujų ląstelių karcinomą, kruopščiai atrenkant pacientus, bei melanomos atvejus paliatyviam tikslui $[10,11]$. Dermatologinès onkologijos darbo grupès (vok. Arbeitsgemeinschaft Dermatologische Onkologie, ADO) gairèse elektrochemoterapija rekomenduojama kaip pakankamus efektyvumo įrodymus turintis alternatyvus odos melanomos metastazių gydymo metodas. Šiuo metu Europoje įsteigta 150 elektrochemoterapijos centru, sukurtos kelios specialios duomenų bazès: Tarptautinis dalijimosi ECT praktika tinklas (angl. International Network for Sharing Practice in ECT, inspECT), Italijos melanomų grupe ir Italijos dermatologinès onkologijos grupè (GIDO). Šios duomenų bazès isteigtos siekiant ištirti elektrochemoterapijos veiksmingumą ir naudingumą, jų inicijuoti klinikiniai tyrimai pagrindè ECT gydymo efektyvumą [12]. Pastarieji klinikiniai tyrimai skirti ECT metodo tobulinimui, ypač jo taikymui sunkiai pasiekiamose vietose.

Kontraindikacijos. Skiriant bleomiciną į veną gali išsivystyti plaučių fibrozè, ypač tiems pacientams, kuriems prieš tai buvo taikyta radioterapija.

Gydant didelio skersmens navikus, dèl sukeliamo naviko griuvimo gali susiformuoti opos. Daugeliu atveju yra didelé tikimybė, kad elektrochemoterapijos procedūrą reiks kartoti. Pacientams, sergantiems lokaliai išplitusia, histologiškai agresyvia ar recidyvavusia bazalinių ląstelių karcinoma, antro elektrochemoterapijos ciklo metu yra didele tikimybé pasiekti pilną atsaką ị gydymą. Atsižvelgiant ị ankstesnes rekomendacijas, ECT metodas nerekomenduotas pacientams, kuriems implantuotas širdies stimuliatorius, sergantiems epilepsija, něščiosioms bei vartojantiems antikoaguliantus. 
Prieš skiriant ši gydymo metodą, visuomet svarbu įvertinti naudos ir žalos santykį, numatomą gyvenimo trukmę bei šalutinio poveikio tikimybę.

Anestezija. Elektrochemoterapijos procedūros metu, siekiant išvengti skausmo bei nemalonių pojūčių, taikoma nejautra, kuri gali būti vietinė arba bendroji.

Jei numatoma, jog atstumas tarp elektrodų ir antkaulio bus mažesnis nei $0,5 \mathrm{~cm}$, tikslinga spręsti dèl bendrinès nejautros pasirinkimo, kadangi vietinè nejautra gali būti nepakankama. Kitas vietinès nejautros pasirinkimo ribojimas yra navikinių mazgelių išsidèstymas vietoje, kuri prieš tai buvo paveikta spindulinès terapijos, - patirtis parodè, jog šios vietos nuskausminamos sunkiau, reikia skirti daugiau analgetikų arba rinktis bendrinę nejautrą. Jei procedūros metu naudojama bendroji anestezija, galimas su ja susijęs šalutinis poveikis.

Elektroporuojant labai mažus navikinius darinius, anestetikai gali būti infiltruojami tiesiai po naviku, nuskausminant elektroporuojamą plotą. Tai leidžia vieno ciklo metu elektroporuoti daugiau židinių. Premedikacija raminamosiomis priemonèmis nebūtina $[5,13]$.

Stebẻjimas. Pirmas vizitas rekomenduojamas praejjus 4 sav. po elektrochemoterapijos procedūros, jei reikia ir anksčiau. Daugeliu atvejų po 4 savaičiu galima ịvertinti gydymo efektą. Esant didesnių pažeidimų, gijimo laikas gali trukti ilgiau. ECT rekomenduojama kartoti po 4 savaičių arba vèliau. Jei navikiniai mazgeliai buvo didesni nei $1,5 \mathrm{~cm}$ diametro, leidžiamas gijimo laikas iki 10 sav., mažesnių - 4-8 savaitès [13].

Klinikinis elektrochemoterapijos veiksmingumas, gydant skirtingos lokalizacijos piktybinius navikus

Melanoma. Elektrochemoterapija yra nauja terapiné galimybė pacientams, kurie serga lokaliai išplitusia melanoma. Remiantis klinikiniu tyrimu, kuriame dalyvavo 61 pacientas iš keturių Europos centrų, parengti metastazavusios melanomos gydymo ECT standartai ESOPE (angl. European standard operating procedures in electrochemotherapy). ECT buvo atliekama, skiriant bleomiciną arba cisplatiną. 20 tyrime dalyvavusiu pacientu sirgo lokaliai išplitusia melanoma, iš viso jiems buvo elektroporuoti 99 odos pažeidimai. Bendras atsakas ị gydymą 80,6 proc., pilnas atsakas $-66,3$ procentai [1].

Geriausių rezultatų buvo pasiekta E. Ricotti ir kt. 2014 metais aprašytame tyrime. Atsako dažnis buvo 100 proc. $(67,28$ proc. atvejų pasiektas pilnas atsakas ir 32,78 proc. - dalinis). Buvo gydyti 24 pacientai (214 odos pažeidimu), kuriems skirti 2 ECT ciklai. Po 24 mėnesių lokali naviko kontrolè buvo pasiekta 72 proc. pacientų [14]. Ši studija įrodė jog ECT metodas gali būti pirmos eilès gydymas pa- liatyviam tikslui, siekiant palengvinti skausmą, sumažinti kraujavimą bei pagerinti pacientų gyvenimo kokybę.

Didelè melanoma sergančiujjų grupè, $2012 \mathrm{~m}$. gydyta ECT metodu, aprašyta L. Campana ir kt. studijoje. Atsako dažnis buvo 92 proc. (pilnas -48 proc., dalinis - 44 proc.). Po dvejų metų stebejimo, išgyvenamumas be ligos progresavimo buvo 87 procentai [15]. Tyrimo rezultatai parodé, jog ECT tinkamiausi pacientai, turintys nedaug nedidelių metastazių apatinèse galūnėse. Tiriamiesiems buvo skirti keli elektrochemoterapijos ciklai.

2017 m. C. Kunte ir tarptautinè komanda paskelbè prospektyvų daugiacentrị tyrimą InspECT, kuriame dalyvavo 151 pacientas. Bendras atsako dažnis buvo 73 proc., stebejjimo trukmè - mažiausiai 60 dienų. Vienerius metus išgyveno 67 proc. pacientų. Dažniausias šalutinis poveikis buvo susijęs su hiperpigmentacija ir opomis (42 proc., 2 pacientai - G3), kiti - skausmas pooperaciniu laikotarpiu (39 proc.), i gripa panašūs simptomai (4 proc.), pykinimas ( 3 proc.) ir patinimas (3 proc.) [16]. Padarytos svarbios išvados dèl ECT indikacijų. Atlikus daugiamatę analizę, veiksniai, teigiamai susiję su bendru atsaku, buvo naviko dydis $<3 \mathrm{~cm}$, visceralinių metastazių nebuvimas, elektroporuotos vietos kur nebuvo taikyta spindulinè terapija, nebuvo limfedemos.

Pastaruoju metu atsiranda klinikinių tyrimų, įrodančių imuninio atsako suaktyvejimą, derinant elektrochemoterapiją ir imunoterapiją. M. Brizio ir kt. paskelbtame tyrime, kurio metu melanomos židiniai odoje buvo gydyti ipilimumabo ir ECT deriniu, navikiniai pakitimai visiškai išnyko [17].

Krūties vėžys ir krūties vėžio metastazės odoje. Krūties véžys yra dažniausia moterų odos metastazių priežastis. Jų atsiradimo tikimybe yra nuo 5 proc. visų segančiųų iki 30 proc. vèlyvose ligos stadijose. Dažniausiai jos nèra tiesioginè mirties priežastis, tačiau turi didelę įtaką pacienčių gyvenimo kokybei, nes sukelia skausmą, išsivysto opos, padidejja infekcijos tikimybe bei sukelia psichologini diskomfortą. Galimais vietiniais ir sisteminiais gydymo metodais dažnai nepavyksta kontroliuoti ligos. Ypatingas iššūkis - gydymas pacienčių, kurioms dèl metastazių apimties negalima atlikti rezekcijos, prieš tai buvo taikyta spindulinè terapija, arba sisteminis gydymas yra neveiksmingas.

2015 m. paskelbtas C. Cabula ir kolegų tyrimas, kuriame elektrochemoterapija buvo gydytos 113 pacienčių (214 židinių), sergančių krūties vèžiu, išplitusiu ị odą. Atsako dažnis buvo 90,2 proc., įskaitant pilną atsaką $-58,4$ procento. 86,2 proc. pacienčių 12 mèn. laikotarpiu nepasireiškè vietinis ligos progresas, o pacientems, kurioms buvo nustatytas pilnas atsakas, šis procentas buvo 96,4 procento [18]. Atliekant daugiamatę analizę, nustatyta, kad statistiškai reikšmingi veiksniai, lemiantys geresni atsaką i gydymą, buvo: naviko dydis $<3 \mathrm{~cm}$, visceralinių metastazių nebuvimas, teigiama 
estrogeno receptoriaus išraiška ir Ki-67 indeksas mažiau nei 14 procentu. Dažniausios komplikacijos: aštrus skausmas per pirmąsias 48 val. po procedūros, 8 proc. pacienčių išsivystė III laipsnio opos ir 8,8 proc. II laipsnio hiperpigmentacija. Geriausi rezultatai stebėti R. Benavento ir kolegų tyrime: jame elektrochemoterapijos metodu buvo gydyta 12 pacienčių (iš viso 142 pažeidimai odoje). Atsakas ị gydymą buvo vertintas po 30 dienų, o stebejjimo mediana - 210 dienų. Atsako dažnis buvo pasiektas 92,3 proc. pacienčiu ( pilnas atsakas $-75,3$ proc., dalinis - 17 proc.) [19].

İdomūs rezultatai pateikti $2014 \mathrm{~m}$. publikuotame L. Campana ir kolegų straipsnyje. Tyrejjai nustatè, kad statistiškai reikšmingai geresni rezultatai buvo pasiekti jaunesnèms nei $70 \mathrm{~m}$. pacientėms, tačiau liga progresavo dažniau toms, kurių amžius nesiekė 70 metų. Lyginant su kitomis terapijomis, ECT pagrindiniai pranašumai yra didelis veiksmingumas, ilga atsako ị gydymą trukmè, nedidelis toksiškumas ir greitas bei visiškas atsigavimas po procedūros. Šiuo metu vyksta elektroporatoriaus ir elektrodų tobulinimas, siekiant išplèsti gydymo galimybès ir taikyti ECT neoadjuvantiniam tikslui, gydant krūties vėží, kai pirminis navikas atitinka T3 ar T4 [20].

Galvos ir kaklo navikai. Pasaulyje tarp vėžinių susirgimų galvos ir kaklo vėžys sudaro apie 6 proc. ir yra šeštoje vietoje pagal paplitimą. Apie 60 proc. pacientų nustatomos vèlyvosios ligos stadijos (III ar IV), jų gydymui rekomenduojamas chirurginis gydymas ir pooperacinè spindulinè terapija, o esant didelès rizikos veiksniams (ekstrakapsuliniam limfmazgio metastazès plitimui ir (ar) infiltruotiems rezekciniams kraštams) - pooperacinis sutaptinis chemospindulinis gydymas platinos preparatais. Nepaisant agresyvių gydymo metodų taikymo, apie 20-50 proc. pacientų nustatomas vietinis ar sritinis recidyvas per pirmuosius dvejus metus po radikalaus gydymo. Nustačius ligos atkrytį, gydymo taktikos pasirinkimas priklauso nuo paciento funkcinès būklès, prieš tai taikyto gydymo, piktybinio proceso išplitimo, gretutinių susirgimų. Šiais atvejais elektrochemoterapijos metodas galètų būti viena iš gydymo galimybių. Europos galvos ir kaklo naviku elektrochemoterapijos tyrimų grupe (EURECA) pasiekè daug žadančių rezultatų, gydant galvos ir kaklo navikus ECT. Rezultatai rodo, jog bendras atsako dažnis buvo 56 procentai (pilnas atsakas - 19 proc., dalinis - 37 proc.) [21].

Elektrochemoterapija yra lokalus ir veiksmingas vietinès naviko augimo kontrolès būdas. Pagrindinè galvos ir kaklo navikų gydymo priemonè išlieka chirurgija ir (arba) spindulinè terapija, tačiau remiantis klinikinių tyrimų duomenimis, elektrochemoterapija galètų būti kaip pagalbinè priemonė citoredukcijos tikslui, išvengiant didelès apimties traumuojančių operacijų. Vietinių recidyvų atvejais, kai nėra kitų gydymo galimybių, ECT gali atlikti pagrindinị gydo- maji vaidmenį. Šiuo metu tiriamas vidinių navikų gydymas endoluminaliniais elektrodais. Ši technologinè plètra gali sudaryti sąlygas gydyti galvos ir kaklo navikus, esančius pakaušio, pogumburio ir skydliaukès liaukose bei navikus gimdos kaklelio srityje.

Sarkomos. Yra dvi pagrindinès sarkomų rūšys - osteosarkoma (kaulų sarkoma), kilusi iš kaulinio audinio, ir minkštujų audinių sarkomos. Tai reta, dažniausiai paauglių ir jaunų žmonių liga, greitai progresuojanti ir sukelianti skausmini sindromą bei invalidizuojanti pacientą. $2013 \mathrm{~m}$. paskelbtame II fazès klinikiniame tyrime, kuriame dalyvavo 34 pacientai, sergantys pažengusia ar metastazavusia minkštujų audinių sarkoma, kai standartinio gydymo galimybès jau buvo išnaudotos. Vidutinis naviko dydis buvo 4 centimetrai. Atsako dažnis buvo 92,2 proc. ( pilno atsako dažnis 32,3 proc.). Dèl nepilno atsako 15 pacientų ECT buvo kartojama iki 4 ciklų, tačiau tai statistiškai reikšmingai nepagerino rezultatų. Stebėsenos mediana buvo 19,3 mènesio. Apskaičiuota, kad dvejus metus stabili liga buvo 72,5 proc. tiriamujjų [22].

$2012 \mathrm{~m}$. paskelbta daugiacentrè retrospektyvi 19 pacienty analizė, sergančių pažengusia angiosarkoma, išplitusia ị odą. Buvo taikyta ECT. Autoriai pranešè, kad po dviejų mėnesių atsako dažnis buvo 63 proc., 6 mènesių išgyvenamumas neprogresuojant ligai - 47 proc. Gydymas paprastai buvo gerai toleruojamas, stebètas vietinių simptomų pagerejjimas: kraujavimo kontrolè (26 proc.), skausmo kontrolè (32 proc.) [23]. Remdamiesi šių pacientų gydymo rezultatais, autoriai padare išvadą, kad ECT gali būti perspektyvus gydymas, siekiant užtikrinti vietinę naviko kontrolę ir simptomų korekciją paliatyviems pacientams, sergantiems paviršinėmis angiosarkomomis.

\section{Klinikinis atvejis}

Aprašomas 80 metų vyro ligos atvejis. Žinoma, kad jis 2013 m. persirgo miokardo infarktu, šiuo metu atliktoje kardioechoskopijoje stebima sumažejusi kairiojo skilvelio išmetimo frakcija (43 proc.).

2015 metais pacientas tirtas dèl kairiosios pèdos hiperpigmentacijos. Diagnozės patikslinimui buvo paimta biopsija, histologiškai patvirtinta Kapoši sarkomos diagnozè. Atlikus radiologinius tyrimus (krūtinès ląstos, pilvo ir dubens organų kompiuterinę tomografiją bei kaulų scintigrafiją), atokiųjų metastazių nenustatyta. Negalint atmesti ŽIV asocijuotos Kapoši sarkomos, atliktas kombinuotas ŽIV (1/2 antikūnų ir p24 Ag antigeno) tyrimas, kuris buvo neigiamas. Remiantis tarptautinemis onkologų rekomendacijomis, $2015 \mathrm{~m}$. liepos mèn. skirta spindulinè terapija ị kairiają pèdą $30 \mathrm{~Gy} / 15 \mathrm{fr}$. kliniškai stebètas pilnas atsakas ị gydymą. Po kelių mėnesių kliniškai nustačius naujus židinius dešiniojoje pėdoje, 2015 m. lapkričio mèn. skirta spindulinè terapija ị dešiniają pẻdą 
30 Gy/15 frakcijų. 2015 gruodžio mèn. nustatytas ligos progresavimas kairiojoje kojoje (1,2 pav.). Radiologiškai atokiųjų metastazių nenustatyta. İvertinus paciento amžių, gretutines ligas, kardiovaskulinę būklę, išnaudotas spindulinės terapijos galimybes, remiantis literatūros duomenimis, nuspręsta taikyti alternatyvų lokalų gydymo metodą - elektrochemoterapiją. Atlikta visų navikinių židinių elektroporacija, naudojant SENNEX ${ }^{\circledR}$ prietaisą. Procedūra atlikta bendrineje nejautroje, skiriant bleomiciną i naviką. Procedūros metu ir po jos komplikacijų nestebèta. Pacientas rytojaus dieną išleistas tęsti ambulatorinị stebejjimą. Pirmam kontroliniam vizitui atvyko praejjus 2 sav. po elektrochemoterapijos. Būklè gera, elektroporuoti židiniai saikiai paraudę, padengti šašais (3 pav.). Atvykus apžiū-
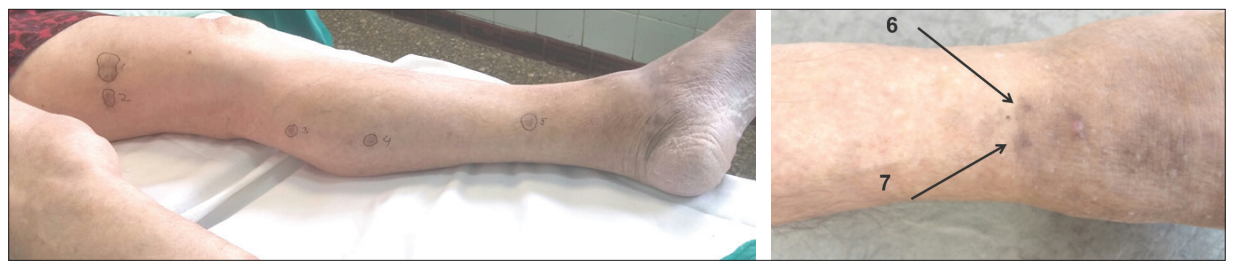

1, 2 pav. Objektyvus ištyrimas
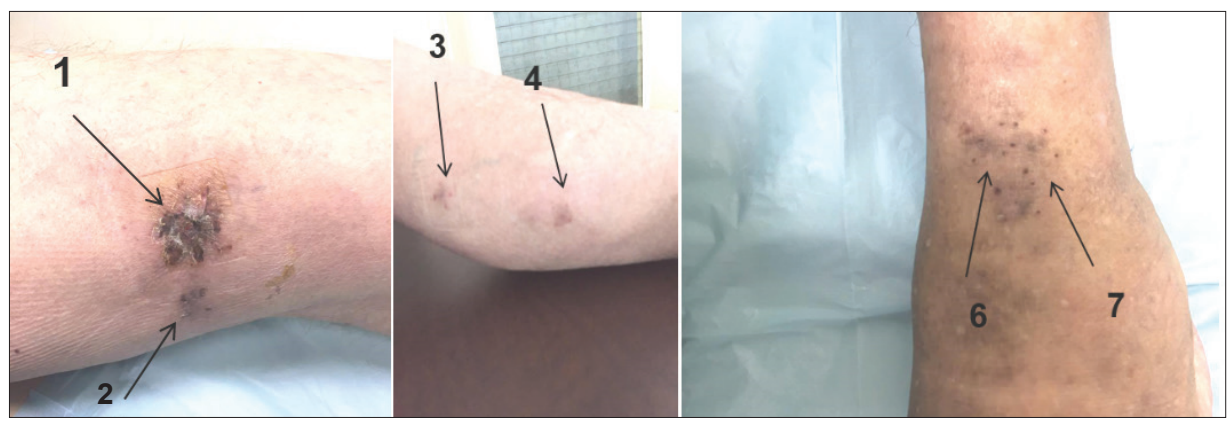

3 pav. Vizitas po 2 savaičių

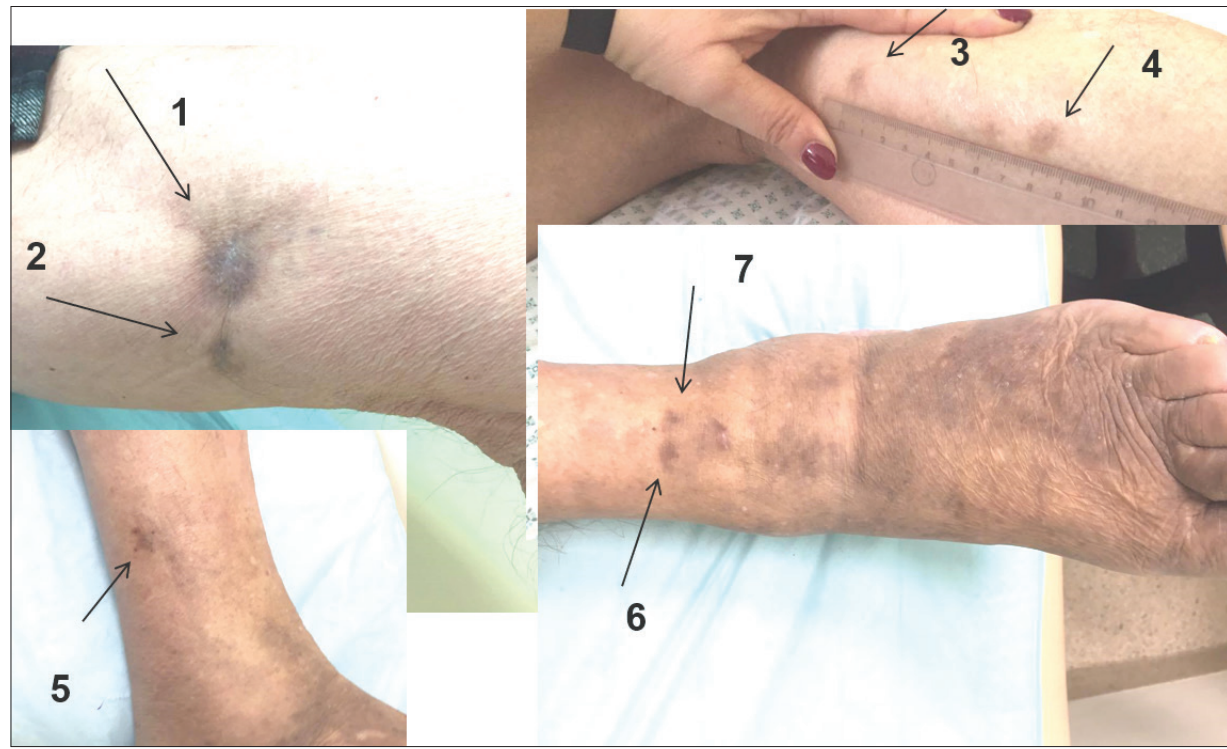

4 pav. Vizitas po 1 mènesio rai po 1 ir 2 mènesių stebima išliekanti hiperpigmentacija kairiojoje kojoje (4, 5 pav.). Tikslinant diagnozę, atlikta kairiosios kojos odos pažeidimų ekscizinè biopsija. Patologinè diagnozè: uždegiminiai rezorbciniai pakitimai. Taikant elektrochemoterapijos metodą šiam pacientui buvo pasiektas pilnas ligos atsakas ị gydymą.

\section{Diskusija}

Pristateme retą ir sėkmingą Kapoši sarkomos atveji, kai gydymui buvo pasirinktas elektrochemoterapijos metodas. Kapoši sarkoma (KS) - tai angioproliferacinis sutrikimas, kurị sukelia žmogaus herpes virusas. Odos pažeidimus gali lydèti ir vidinių organų pažeidimai. Aprašomi keturi Kapoši sarkomos tipai: 1) klasikine Kapoši sarkoma dažniausiai serga vyresnio amžiaus vyrai (Viduržemio jūros ir Rytų Europos regionuose); 2) endeminio tipo KS serga jauni Subsacharos regiono afrikiečiai; 3) jatrogeniniu tipu serga ịvairaus amžiaus žmonès, vartojantys imunosupresinius vaistus po organų transplantacijos; 4) ŽIV asocijuota Kapoši sarkoma pasireiškia ŽIV infekuotiems ir AIDS sergantiems. Liga dažniausiai pažeidžia odą ir gleivines, virškinimo, kvėpavimo organus. Klasikinès KS eiga paprastai vangi, dažniausiai pasireiškia raudonomis ar violetinèmis dèmèmis apatinèse galūnèse. Afrikinè endeminė ir ŽIV asocijuota Kapoši sarkoma paprastai yra agresyvesnès eigos. Diagnozè patvirtinama odos biopsija, gali būti atliekami vidaus organų radiologi- 
niai tyrimai [24]. Lokalios Kapoši sarkomos atveju gali būti skiriama spindulinè terapija, krioterapija, operacija arba elektrochemoterapija. Išplitusios ligos atveju - chemoterapija arba imunoterapija [25].

\section{Išvados}

1. Elektrochemoterapija yra saugus ir veiksmingas navikinių pažeidimų, esančių odoje ir poodyje, gydymo metodas, nepriklausomai nuo histologinio tipo ir prieš tai taikyto gydymo. Atsiranda naujų tyrimų, irodančių ECT efektyvumą, gydant tiek pirminius, tiek metastatinius darinius ivvairiuose vidaus organuose (pvz., kepenyse, kauluose, kasoje).

2. Vienas iš pagrindinių
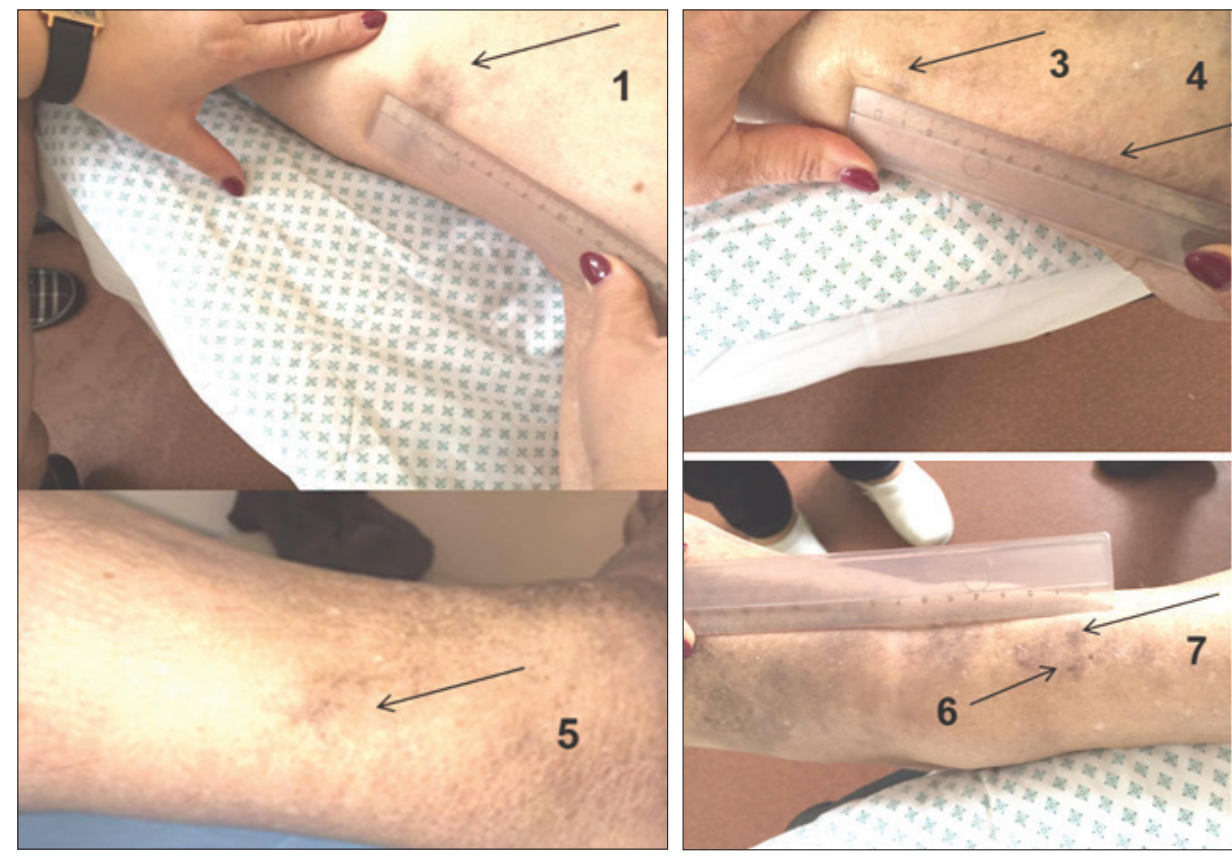

5 pav. Vizitas po 2 mènesių

ECT privalumų yra trumpas hospitalizacijos laikas. ECT gali būti atliekama dienos stacionare. Šis metodas yra kartotinas ir derinamas su kitomis terapijomis, ekonomiškai palankus, vertinant kainos ir efektyvumo santykį, sunkių nepageidaujamų reiškinių neužregistruota. Dèl šio metodo naujumo reikia daugiau mokslinių tyrimų, kad būtų galima plettoti ECT ir padaryti ją labiau tinkamą ịvairių rūšių vėžiui, taip pat ir kitoms ligoms gydyti.

\section{Literatūra}

1. Marty M et al. Electrochemotherapy - an easy effective and safe treatment of cutaneous and subcutaneous metastases: results of ESOPE study. EJC Supplements 2006;4:3-13.

https://doi.org/10.1016/j.ejcsup.2006.08.002

2. Mir LM, Belehradek M, Domenge C, Orlowski S, Poddevin B, Belehradek J, Schwaab G, Luboinski B, Paoletti C. Electrochemotherapy, a novel antitumour treatment: first clinical trial. C R Acad Sci Paris 1991;313:613-8.

3. Gothelf A, Mir LM, Gehl J. Electrochemotherapy: results of cancer treatment using enhanced delivery of bleomycin by electroporation. Cancer Treat Revs 2003;29:371-87. https://doi.org/10.1016/S0305-7372(03)00073-2

4. Sersa G, Cemazar M, Rudolf Z. Electrochemotherapy: advantages and drawbacks in treatment of cancer patients. Cancer Ther 2003;1:133-42.

5. Mir LM, Sersa G et al. Standard operating procedures of the electrochemotherapy: instructions for the use of bleomycin or cisplatin administered either systemically or locally and electric

pulses delivered by the Cliniporator by means of invasive or non-invasive electrodes. EJC Supplements 2006;4:14-25.

https://doi.org/10.1016/j.ejcsup.2006.08.003

6. Sersa G, Stabuc B, Cemazar M, Miklavcic D, Rudolf Z. Electrochemotherapy with cisplatin: clinical experience in malignant melanoma patients. Clinical Cancer Research 2000;6(3):863-7.

7. Gehl J, Sersa G, Matthiessen LW et al. Updated standard operating procedures for electrochemotherapy of cutaneous tumours and skin metastases. Acta Oncologica 2018;57(7):874-882. https://doi.org/10.1080/0284186X.2018.1454602

8. Cadossi R, Ronchetti M, Cadossi M. Locally enhanced chemotherapy by electroporation: clinical experiences and perspective of use of electrochemotherapy. Future Oncology 2014;10:877-890.

https://doi.org/10.2217/fon.13.235

9. Colombo GL, Matteo SD, Mir LM. Cost-effectiveness analysis of electrochemotherapy vs other methods for the control and treatment of cutaneous and subcutaneous tumors. Therapeutics and Clinical Risk Management 2008;4(2):541-8.

https://doi.org/10.2147/TCRM.S2780

10. National Institute for Health and Care Exellence. Electrochemotherapy for primary basal cell carcinoma and primary squamous cell carcinoma. NICE guidance 2014.

https://www.nice.org.uk/ guidance/ipg478.

11. National Institute for Health and Care Exellence. Electrochemotherapy for metastases in the skin from tumours of nonskin origin and melanoma. NICE 2013.

https://www.nice.org.uk/ guidance/ipg446. 
12. Sersa G, Miklavcic D, Cemazar M et al. Electrochemotherapy in treatment of tumours. European Journal of Surgical Oncology 2008;34(2):232-240.

https://doi.org/10.1016/j.ejso.2007.05.016

13. Mir LM. Bases and rationale of the electrochemotherapy. European Journal of Cancer Supplements 2006;11:38-44. https://doi.org/10.1016/j.ejcsup.2006.08.005

14. Ricotti E, Giuliodori K, Cataldi I, Campanati A, Ganzetti G, Ricotti G, Offidani A. Electrochemotherapy: an effective local treatment of cutaneous and subcutaneous melanoma metastases. Dermatologic Therapy 2014;27:148-52.

https://doi.org/10.1111/dth.12098

15. Campana LG, Valpione S, Mocellin S, Sundararajan R, Granziera E, Sartore L, Chiarion-Sileni V, Rossi CR. Electrochemotherapy for disseminated superficial metastases from malignant melanoma. Br J Surg 2012;99:821-30.

https://doi.org/10.1002/bjs.8749

16. Kunte C, Letule V, Gehl J, et al. Electrochemmotherapy in the treatment of metastatic malignant melanoma: a prospective cohort study by InspECT. Br J Dermatol 2017;176(6):1475-85. https://doi.org/10.1111/bjd.15340

17. Brizio M, Fava P, Astrua C, Cavaliere G, Savoia P. Complete regression of melanoma skin metastases after electrochemotherapy plus ipilimumab treatment: an unusual clinical presentation. Eur J Dermatol 2015;25:271-2.

https://doi.org/10.1684/ejd.2015.2522

18. Cabula C, Campana LG, Grilz G, et al. Electrochemotherapy in the treatment of cutaneous metastases from breast cancer: a multicenter cohort analysis. Ann Surg Oncol 2015;22:442-450. https://doi.org/10.1245/s10434-015-4779-6

19. Benavento R, Santoriello A, Perna G, et al. Electrochemotherapy of cutaneous metastases from breast cancer in elderly patients: a preliminary report. BMC Surg 2012;12(suppl 1):6. https://doi.org/10.1186/1471-2482-12-S1-S6

20. Cabula C. Neoadjuvant electrochemotherapy of breast cancer: our experience on first case treated in Italy. Updates Surg 2013;65:325-328. https://doi.org/10.1007/s13304-012-0170-3

21. Virgilio AD, Ralli M, Longo L, Mancini P et al. Electrochemotherapy in head and neck cancer: a review of an emerging cancer treatment. Oncol Lett 2018;16(3):3415-3423.

https://doi.org/10.3892/ol.2018.9140

22. Campana LG, Bianchi G, Mocellini S, Valpione S et al. Electrochemotherapy treatment of locally advanced and metastatic soft tissue sarcomas: results of a non-comparative phase II study. World J Surg 2014;38(4):813-22.

https://doi.org/10.1007/s00268-013-2321-1

23. Sersa G, Cufer T, Paulin SM, Cemazar M and Snoj M. Electrochemotherapy of chest wall breast cancer recurrence. Cancer Treat Rev 2012;38:379-386.

https://doi.org/10.1016/j.ctrv.2011.07.006

24. Vilkaitė A., Vengelytė G., Kučinskienė V. Kapoši sarkoma. Lietuvos gydytojo žurnalas. 2020;1(123):19-21.

25. Tsao MN, Sinclair E, Assaad D, Fialkov J, Antonyshyn O, Barnes E. Radiation therapy for the treatment of skin Kaposi sarcoma. Annals of palliative medicine 2016;5:238-241.

https://doi.org/10.21037/apm.2016.08.03

\section{EFFECTIVENESS OF ELECTROCHEMOTHERAPY IN TREATING CANCER TUMORS: LITERATURE OVERVIEW AND CLINICAL CASE}

\section{G. Chlebopaševienė, R. Jančiauskienė, S. Liutkauskienė,}

I. Padvelskienė, S. Šatkauskas, E. Juozaitytė

Keywords: electrochemotherapy, Kaposi sarcoma, cisplatin, bleomycin.

Summary

Chemotherapy is a standardized cancer therapy with one or several drugs that destroy tumor cells and stop them from growing. Effectiveness of chemotherapy is even higher when this treatment is combined with other therapies combatting cancer tumors (surgery, radiotherapy). Unfortunately, sometimes we struggle with the problem that this therapy is not effective when treating tumors in some localizations. At times, this derives from biological characteristics of the drug (hydrophilicity, large molecular mass) and therefore, the drug's permeability into membrane of tumors cells is weak and drug does not have the expected impact. In order to achieve the desired impact, the medicine has to be prescribed in large doses and as a result, undesirable effects of drug affect suffering patients. One of the possibilities to increase the effectiveness of medicine that shrink tumors is a combination of electric pulses together with medicine against cancer. This combination of therapies is called electrochemotherapy (ECT). Electric pulses cause changes in cell membrane, cell is destabilized, formation of temporary pores (electroporation) takes place. Therefore, permeability of membrane increases for outer substances and as a result, medicine that in usual circumstances struggles to penetrate to the cell, can easily reach its target.

Correspondence to: greta.chlebopaseviene@kaunoklinikos.lt

Gauta 2021-02-27 